\title{
Computer-assisted Language Learning for the Development of Listening Skills: A Case Study of Pre-university Russian as a Foreign Language
}

\author{
Maria Yu. Lebedeva (Corresponding author) \\ Pushkin State Russian Language Institute, 6 Ac. Volgina str., Moscow 117485, Russia \\ E-mail: maria.y.lebedeva@mail.ru
}

E.V. Koltakova

Pushkin State Russian Language Institute, 6 Ac. Volgina str., Moscow 117485, Russia

Olga N. Khaleeva

Pushkin State Russian Language Institute, 6 Ac. Volgina str., Moscow 117485, Russia

M.N. Rusetskaya

Pushkin State Russian Language Institute, 6 Ac. Volgina str., Moscow 117485, Russia

Received: 14-07-2016

Published: 02-01-2017
Accepted: 27-09-2016

doi:10.7575/aiac.ijalel.v.6n.1p.257
Advance Access Published: November 2016

URL: http://dx.doi.org/10.7575/aiac.ijalel.v.6n.1p.257

\begin{abstract}
The research explores the effectiveness of using computer-assisted language learning (CALL) approach for the development of non-reciprocal listening skills in the context of studying Russian as a foreign language (RFL). Despite the fact that the influence of CALL on the development of listening skills has been well studied based on a case study of teaching other languages (especially English), a similar study in the context of teaching the Russian language is performed for the first time. The RFL students $(\mathrm{N}=68)$ and teachers $(\mathrm{N}=7)$ of the Preparatory Department in Russian took part in the intervention study. The students were divided into experimental and control groups. The research was conducted based on both qualitative and quantitative methods. The researchers focused the attention on two kinds of listening: listening for general information and selective listening. As the listening competence, and especially academic listening proficiency, is critically important for the students of the preparatory department, he researchers' target was to research ways of improving listening abilities with different approaches of using CALL. The testing and assessment materials were developed and the statistics was collected for each kind of listening. In addition, the students of the experimental group were surveyed to identify their experiences from using CALL in the classroom. The research findings allowed concluding about the effectiveness of CALL application for developing listening for the detail skills, whereas in the general listening no significant effect was found. In addition, the study revealed specific complexities in the application of CALL in teaching listening in Russian.
\end{abstract}

Keywords: computer-assisted language learning, web-based instruction, listening comprehension, blended learning, Russian as a foreign language

\section{Introduction}

Computer-assisted language learning (CALL), or as it is also known 'TELL' (technology enhanced language learning), is becoming increasingly widespread throughout various educational institutions and systems in a number of countries. Russia is no exception.

According to the official statistics provided by UNESCO Institute for Information Technologies in Education and expert estimates, technology has been smoothly integrated into Russian education. The reason for this can mainly be attributed to the results of several Federal Targeted Programmes and national projects, as well as private initiatives (Sigalov \& Skuratov 2012).

During the last decade, the area of Russian as Foreign Language (RFL) learning has significantly utilized technology and online resources which has, in turn, led to an increased research interest in using CALL in RFL classroom.

Since the 1950s, when computers were first being used for language learning (Beatty, 2010), researchers have accumulated considerable expertise in this area (refer to overviews and meta-analyses, e.g. Warschauer \& Kern, 2000; Bax, 2003; Zhao, 2003; Davies, 2005; Felix, 2008; Levy, 2009; Hubbard, 2009; Chambers, 2010; Butler-Pascoe, 2011; Grgurović, Chapelle and Shelley, 2013). 
The benefits, current limitations and perspectives of applying CALL to the development of listening skills were discussed broadly by Hsu, 1994; Brett, 1995; Jakobsdottir and Hooper, 1995; O'Bryan and Hegelheimer, 2007; Roussel, 2011; Barani, 2011; Nachoua, 2012; Chen, Zhang and Liu, 2013. Many of the experts focused on multimodal opportunities of computer-assisted listening learning, claiming that the aural text accompanied by visual input modes, such as captions, subtitles and transcripts leads to better comprehension and therefore reduces cognitive load (Wakabayashi 1998, Jones, 2006; Jones, 2009; Winke, Gass and Sydorenko, 2010; Taylor, 2005). Seo (2002), Sueyoshi and Hardison (2005), and Gruba (2006) investigated the role of a videotext as a special educational genre in technologymediated communication. The problems and silutions of using technology and multimedia for monologic nonreciprocal listening skills for the academic purposes were examined by Chapelle 2003, Smidt and Hegelheimer 2004.

Some of the studies explored the learners' reflections on the technology enhanced language learning, and listening skills development in particular. Hegelheimer and Tower (2004) analysed the learners' experience on using CALL during the language classes; Jones (2003) investigated the impact multimedia annotations have on listening comprehension from the students' stand. It is hardly surprising that most of learners find that online language-learning environments are more effective and motivating than textbook-based materials and paper-and-pencil tasks (Soboleva \& Tronenko, 2002).

Considering computer-assisted Russian language learning as a part of the general CALL field, we realize, however, that it is not always appropriate to extrapolate findings received in other contexts, to RFL context. The specific linguistic features, students' level of language proficiency, the basic approach to language learning they used to, the students' and teachers' attitude to technological learning tools - are all factors that shape the results of using CALL in authentic classrooms. Following Bax's (2003) suggestion to run "more in-depth ethnographic studies of individual environments to elucidate the relationship" between the different factors in CALL (Bax, 2013: 27), we explore the case of integrating CALL into RFL classroom at the preparatory department of Pushkin State Russian Language Institute.

\section{Context}

The study was undertaken between March and May 2016, covering a period of 2 months. The students and instructors of the preparatory department were participants of the study.

The preparatory department aims to prepare foreign students who have not yet met the Russian language proficiency requirement, to enter Russian universities, through focusing on both language and subject proficiency. Most of the students are 'absolute' and 'false' RFL beginners when they start attending classes within the preparatory department.

An academic year lasts for 38 weeks, two semesters. The autumn semester is entirely devoted to Russian language classes with a total of 510 hours of instruction. During the spring semester, students continue studying RFL (408 hours of instruction) and attend special history, social studies, and literature classes. These are all conducted in Russian. By the end of the academic year, students are expected to complete the B1 level of general RFL proficiency and gain basic skills of Russian for academic purposes in humanities.

In order to enrich the educational environment and to provide extra opportunities for RFL learners, Pushkin State Russian Language Institute has developed a digital platform under the brand "PushkinOnline", which contains materials to cover all 6 levels of RFL for both self-paced and tutor-facilitated learning.

The main challenges the preparatory department deals with are probably common to the majority of undergraduate preparation programs: limit of contact hours to achieve the outcome, especially regarding the communicative competence development; multi-socio-cultural backgrounds of learners (such as their native language, previous experience of learning foreign languages etc.); varying academic aims of learners (plans for applying to different faculties).

The listening competence, and especially academic listening proficiency, is critically important for the students of the preparatory department, but, with limited contact hours, it is awkward to foster the listening skill at a satisfactory level. CALL implementation within the blended learning model seems to be a viable solution, and requires to be examined carefully in order to find the proper strategies and anticipate the difficulties.

Listening to academic lectures requires the ability both to highlight important conceptual information and extract detailed information from aural texts on scientific and professional subject matters. As academic listening is mainly of non-reciprocal nature, this study focuses on the development of such type listening proficiency. The study aims to measure the impact that CALL has on developing L2 non-reciprocal listening skill and to answer the following research questions:

RQ1. What is the effect of a computer-assisted approach on RFL non-reciprocal listening skills development?

RQ2. What are the perceptions of students towards the use of online learning resource for the listening learning?

\section{Methodology}

\subsection{Participants}

The study involved 7 intact groups of the preparatory department, with a total of 68 male and female students from 18 countries (Azerbaijan, Afghanistan, Bulgaria, Brazil, Chad, China, Côte d'Ivoire, France, India, Jordan, Laos, Mongolia, Spain, South Korea, Syria, Venezuela, Vietnam, and Zimbabwe) and 7 regular group instructors aged 25-32 years. The pre-test determined the initial homogeneity of students' RFL level, which varied from A2 (in 5 groups) to B1 (2 groups). The intact groups were randomly assigned to either experimental (total of 35 students, including 1 group of B1 learners) or control group (total of 33 students, including 1 group of B1 learners, respectively). Participants were 
unaware of which group they belonged.

As further investigated by the pre-intervention questionnaire, most of students had an experience of using web-based resources in language learning $(\mathrm{N}=58 ; 85 \%)$, but only few of them were aware of any digital resources for Russian learning $(\mathrm{N}=7 ; 10 \%)$. More than three quarters $(\mathrm{N}=52 ; 76 \%)$ consider web-based resources effective for foreign language learning.

\subsection{Material selection}

One of the most important criteria for evaluating language learning digital resources is the "transmission of the four language skills (listening, speaking, reading, and writing) to learners" (Yang and Chan, 2008). PushkinOnline general RFL courses are organized by topics constructed on the correlation between the four skills. The topic presentation and students' activity within it is divided into small chunks, starting with warming-up activities. It continues through introducing the language units, to the language usage both in receptive and productive skills.

Supporting the syllabus of the preparatory department, the topic "Biography" was chosen for the experiment. This included subtopics "Autobiography", "Biography of a famous person", "Self-presenting for an interview" and "Introducing yourself in a public institution", which provided the presentation of the main topic in the various sociolinguistic contexts. According to the research objective the materials for listening development were chosen, including a pre-listening stage with problem vocabulary and grammar items presentation (Figures 1-3).

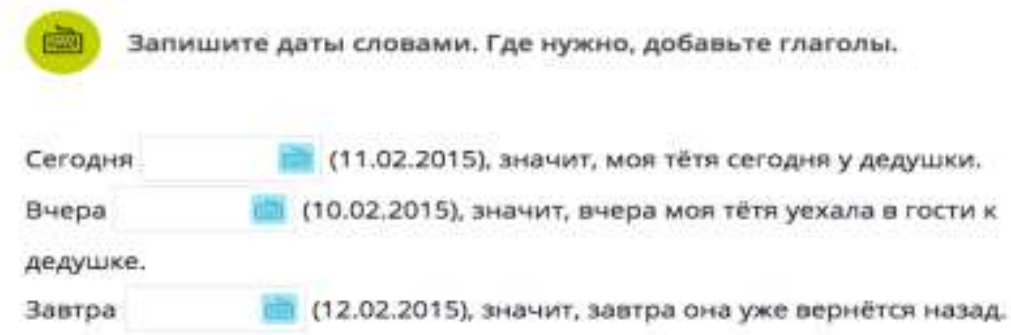

Figure 1. A pre-listening grammar activity (writing dates in Russian).

Note: translation of the task: "Write the numbers in words. Add the verbs if necessary".

10. Послушайте рассказ Элизабет о себе. Выберите правильный ответ.

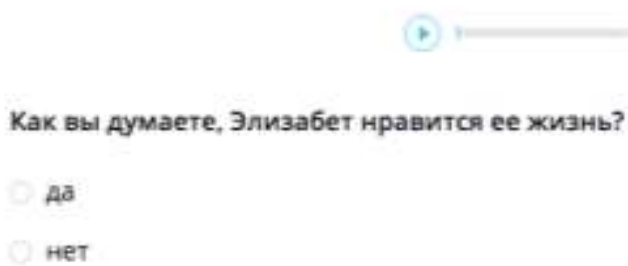

Figure 2. The question on general gist of the text.

Note: translation of the task: "Listen to Elizabeth's story. Choose a correct answer".

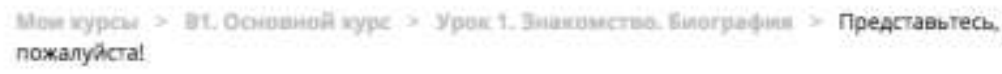

Послушайте рассказ Али. Впечатайте пропущенные цифры.

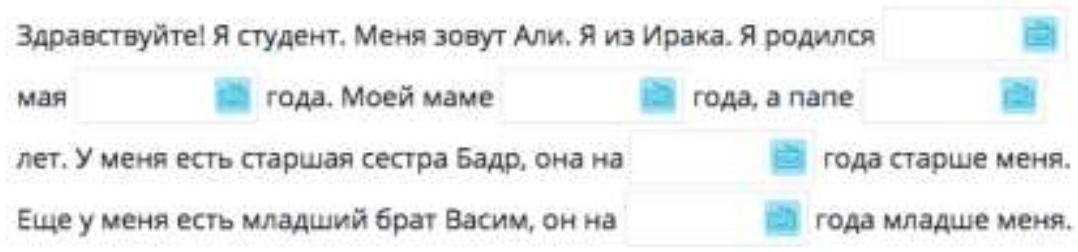

Figure 3. Fill-in-blanks items on detailed information (dates and numbers)

Note: translation of the task: "Listen to Ali's story. Fill the gaps with proper numbers". 


\subsection{Procedure}

The pre-intervention part of the study included:

- $\quad$ the questionnaire for students about their experience of using digital resources in language learning;

- the pre-test detecting the students' general level of RFL proficiency designed as a regular TORFL (Test of Russian as Foreign Language) and the subtest diagnosed their listening performance level.

The listening subtest included two aural texts, each consisted of two parts. The first part was aimed to evaluate the students' ability to understand the main idea and the main points of what they heard. It was designed as a multiple choice test with 10 items for each of the text (20 in total). The second part was composed of 15 fill-in-the-blank items (30 in total for both texts) intended to evaluate students' skill of understanding detailed information. The test covered the topics and language items that had already been learned within the course.

The experimental group treatment was conducted in two steps. Prior to the intervention, the instructors of the experimental group completed a training workshop on how to use "PushkinOnline" as a supplementary online resource and on implementing it into a blended learning course. Previous cases of constructing blended learning courses for English as a foreign language served as examples (Tomlinson and Whittaker, 2013). In contrast, the instructors of the control group were not involved in the workshop.

As a result of the workshop, the instructors received the pedagogical materials describing the procedure (based on Rost's (2002), and Wilson's (2008) technique) they would follow during the intervention classes (Table 1). To deliver the digital resources to the brick-and-mortar classroom, personal laptops were provided for each participant. To keep accordance with the blended models typology as outlined by Horn and Staker (2014), the rotation model was applied.

Table 1. The stages of the intervention classes

\begin{tabular}{|c|c|c|}
\hline Pedagogical stage & Teacher and students activity & Purpose \\
\hline Topic introduction & $\begin{array}{l}\text { Speaking about related topics, discussing } \\
\text { the main concepts }\end{array}$ & $\begin{array}{l}\text { Motivating, activating prior and } \\
\text { world knowledge, narrowing field } \\
\text { of expectation, reducing anxiety }\end{array}$ \\
\hline $\begin{array}{l}\text { Presentation of } \\
\text { previously unlearnt } \\
\text { lexical items and } \\
\text { grammar structures }\end{array}$ & $\begin{array}{l}\text { The students individually work with } \\
\text { "PushkinOnline" }\end{array}$ & $\begin{array}{l}\text { Providing the language units } \\
\text { necessary for text comprehension, } \\
\text { reducing anxiety }\end{array}$ \\
\hline $\begin{array}{l}\text { The first } \\
\text { pre-listening task }\end{array}$ & $\begin{array}{l}\text { The teacher clarifies what will be asked } \\
\text { after listening to the text (general } \\
\text { information) }\end{array}$ & $\begin{array}{c}\text { Activating short-memory } \\
\text { processes, motivating, reducing } \\
\text { anxiety }\end{array}$ \\
\hline The first listening stage & $\begin{array}{l}\text { Students individually listen to the text on } \\
\text { the "PushkinOnline" and take notes }\end{array}$ & $\begin{array}{l}\text { Listening for general information } \\
\text { and main concepts }\end{array}$ \\
\hline $\begin{array}{l}\text { The first post-listening } \\
\text { task }\end{array}$ & $\begin{array}{l}\text { The teacher asks the questions on } \\
\text { general information. Students discuss } \\
\text { what they heard and what helped them to } \\
\text { comprehend the text. The attention is } \\
\text { paid to both formal and semantic features } \\
\text { of the genre (biography). }\end{array}$ & $\begin{array}{l}\text { Enhancing appropriation of the } \\
\text { content and listening skills, } \\
\text { developing listening strategies, } \\
\text { genre analysis }\end{array}$ \\
\hline $\begin{array}{l}\text { The second pre-listening } \\
\text { task }\end{array}$ & $\begin{array}{l}\text { The teacher clarifies what will be asked } \\
\text { after listening to the text (detailed } \\
\text { information: names, places, dates) }\end{array}$ & $\begin{array}{c}\text { Activating short-memory } \\
\text { processes, motivating, reducing } \\
\text { anxiety }\end{array}$ \\
\hline $\begin{array}{l}\text { The second listening } \\
\text { stage }\end{array}$ & $\begin{array}{l}\text { The students individually listen to the } \\
\text { same text on the "PushkinOnline" and } \\
\text { take notes }\end{array}$ & Selective listening \\
\hline $\begin{array}{l}\text { The second } \\
\text { post-listening task }\end{array}$ & $\begin{array}{l}\text { The students complete post-listening } \\
\text { tasks on the "PushkinOnline" in pairs or } \\
\text { small groups and get immediate } \\
\text { feedback. The results are discussed with } \\
\text { the teacher. }\end{array}$ & $\begin{array}{c}\text { Enhancing appropriation of the } \\
\text { detailed information and listening } \\
\text { skills, developing listening } \\
\text { strategies }\end{array}$ \\
\hline
\end{tabular}

The post-intervention part of the study included the delayed listening post-test, which had the same structure as the listening pre-test and based on the topic "Biography"; two texts selected for the listening correlated with the topics "Autobiography" and "Biography of a famous person". The tests were conducted in paper version in both the experimental and the control groups in order to provide the equal conditions.

Also, the anonymous survey about participants' perceptions of their experience of working with PushkinOnline was conducted online and in paper mode after the intervention and the post-assessment stages in the experimental group. The survey results were supplemented by the small amount of qualitative data collected from participants' written reflections. 


\section{Data analysis and discussion}

\subsection{Pre-test and post-test results}

Figures 4 and 5 show the difference in students' performance during the pre-test and post-test conducted in the experimental and the control group, respectively (the results are sorted from the lowest to the highest score).

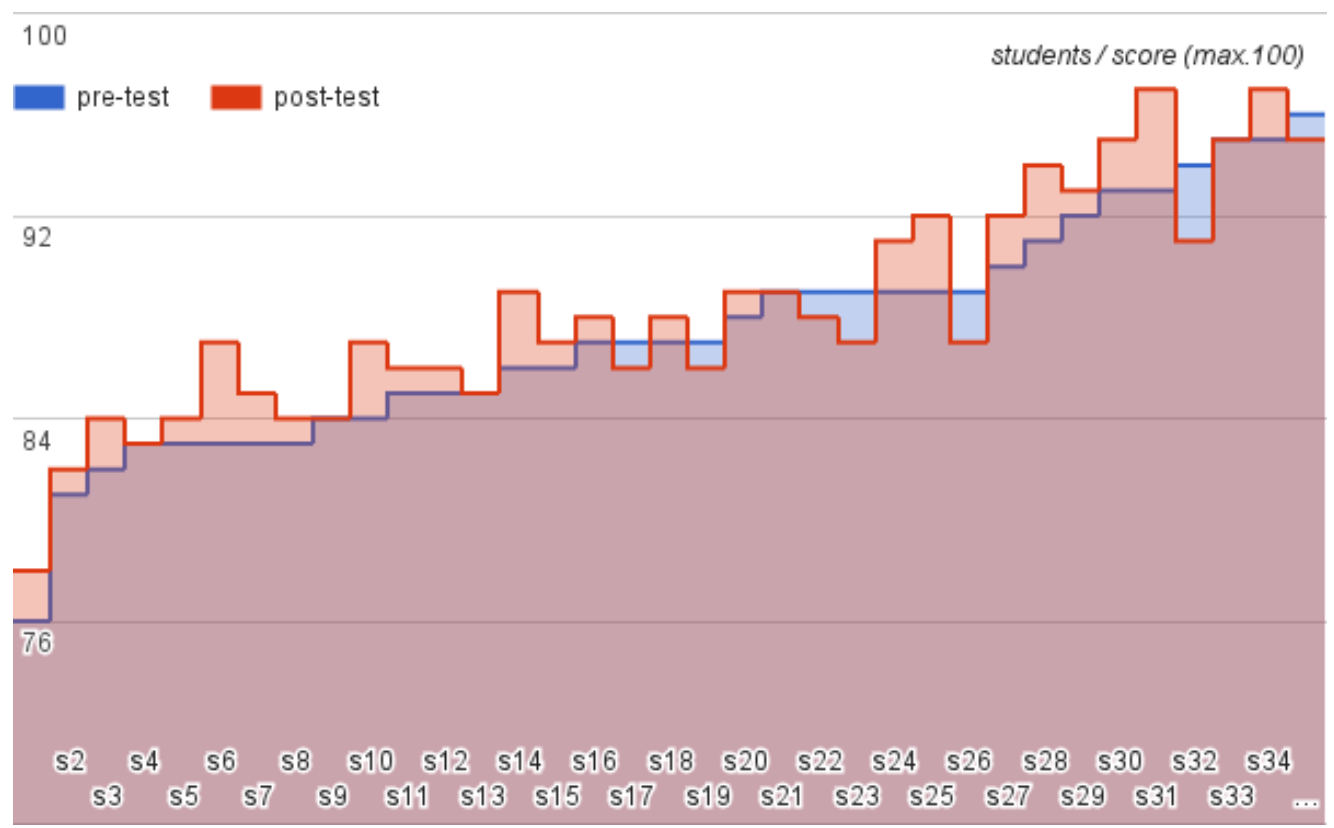

Figure 4. Students' performance during the pre-test and the post-test: the experimental group.

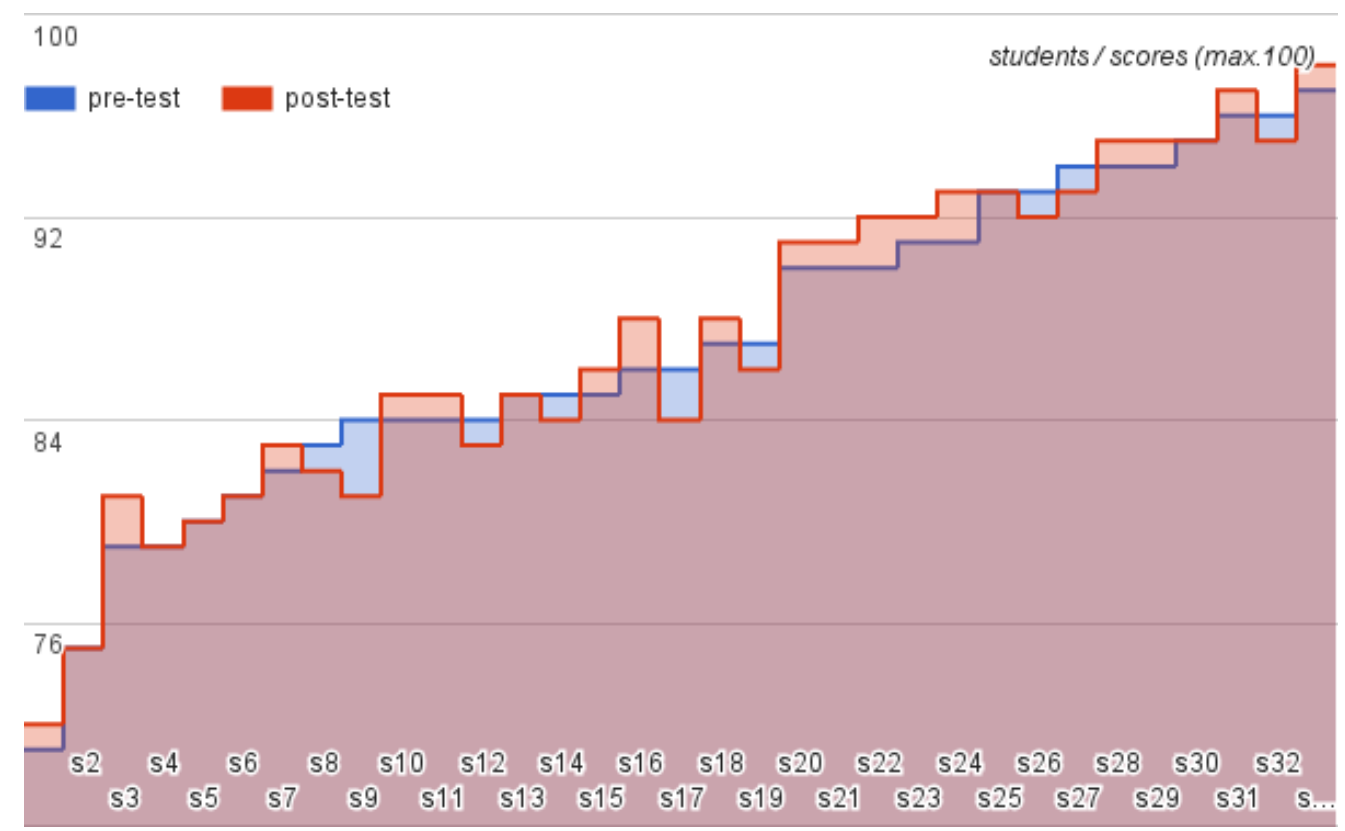

Figure 5. Students' performance during the pre-test and the post-test: the control group.

To verify the homogeneity of the experimental and control group in terms of their listening proficiency, an independentsample $t$-test was applied before the treatment (Table 2). It indicated that there was no statistically significant difference between these two groups $\left(\mathrm{t}(66)=0.2779, \mathrm{t}_{\mathrm{o.05}}(66)=2\right)$.

Table 2. Independent-sample $t$-test for the experimental and control group in the pre-test

\begin{tabular}{|c|c|c|c|c|c|}
\hline & \multirow[t]{2}{*}{$\mathrm{t}$} & \multirow[t]{2}{*}{$\mathrm{df}$} & \multirow[t]{2}{*}{$\begin{array}{l}\text { Std. error } \\
\text { difference }\end{array}$} & \multicolumn{2}{|c|}{$\begin{array}{l}95 \% \text { confidence interval of } \\
\text { the difference }\end{array}$} \\
\hline & & & & lower & higher \\
\hline Pre-test & 0.2779 & 66 & 0.932 & -1.81 & 1.99 \\
\hline
\end{tabular}


detailed information. The difference between the students' performance was calculated separately for each part. Table 3 provides more precise statistics on the comparison between the experimental and the control group in terms of average score (M), standard deviation (SD) and the difference in the results of pre- and post-test $(\Delta)$.

Table 3. Descriptive statistics for the experimental and control group in the pre- and post-test

\begin{tabular}{|c|c|c|c|c|}
\hline & & & $\begin{array}{l}\text { Experimental group } \\
(\mathrm{N}=35)\end{array}$ & $\begin{array}{c}\text { Control group } \\
(\mathrm{N}=33)\end{array}$ \\
\hline \multirow{5}{*}{$\begin{array}{l}\text { The overall result } \\
(\max .100)\end{array}$} & \multirow[t]{2}{*}{ Pre-test } & M & 87.37 & 87 \\
\hline & & SD & 4.53 & 6.39 \\
\hline & \multirow[t]{2}{*}{ Post-test } & M & 88.31 & 87.27 \\
\hline & & SD & 4.48 & 6.54 \\
\hline & & $\Delta$ & 0.94 & 0.27 \\
\hline \multirow{5}{*}{$\begin{array}{l}\text { Part 1: general } \\
\text { information } \\
(\max .40)\end{array}$} & \multirow[t]{2}{*}{ Pre-test } & $\mathrm{M}$ & 35.83 & 35.67 \\
\hline & & SD & 2.36 & 2.35 \\
\hline & \multirow[t]{2}{*}{ Post-test } & M & 36.23 & 35.88 \\
\hline & & $\mathrm{SD}$ & 2.37 & 2.36 \\
\hline & & $\Delta_{1}$ & 0.4 & 0.21 \\
\hline \multirow{5}{*}{$\begin{array}{l}\text { Part 2: detailed } \\
\text { information } \\
(\max .60)\end{array}$} & \multirow[t]{2}{*}{ Pre-test } & $\mathrm{M}$ & 51.54 & 51.33 \\
\hline & & SD & 3.97 & 4.61 \\
\hline & \multirow[t]{3}{*}{ Post-test } & M & 52.08 & 51.39 \\
\hline & & SD & 3.93 & 4.9 \\
\hline & & $\Delta_{2}$ & 0.54 & 0.06 \\
\hline
\end{tabular}

Note: $\Delta-$ is the mean difference in scores of the pre-test and post-test (the average progress).

The difference in the means between the experimental group pre-test scores $(M=87.37, S D=4.52)$ and post-test scores $(M=88.31, S D=4.48)$ is less than one $(\Delta=0.94)$. In other words, the results of Table 3 indicate the limited positive influence of CALL on the participants' ability to comprehend Russian aural text on the learned topic. The comparison with the data of the control group shows the negligible difference between the results of utilizing CALL and the results of using traditional pedagogical approach $(0.67)$.

Examining the results received in each part of the test establishes more detailed picture. In general, the students of the experimental group experienced greater progress than the control group participants in both parts of the test: for the experimental group $\Delta_{l}=0.4$ and $\Delta_{2}=0.54$ comparing to the control group progress, where respectively $\Delta_{l}=0.21$ and $\Delta_{2}=0.06$. But, the between-group differences were larger in the second part of the test: the difference in the progress of two groups was 0.48 . Thus, the quantitative data of the experiment indicates that CALL approach is most effective in developing selective listening.

\subsection{Survey results}

The survey included 10 Likert rating scale questions adapted to the participants' level of Russian. The last question (marked with the asterisk) was followed by the open-ended question aimed to clarify the particular problems. In total 35 students of the experimental group completed the questionnaire; the statistical data is presented in Table 4.

Table 4. Perceptions of utilizing PushkinOnline for the development of listening skills

\begin{tabular}{lcc}
\hline \multicolumn{1}{c}{ Questions with ratings 1 low/disagree to 5 high/agree } & M & SD \\
\hline 1. I liked the lesson based on the use of PushkinOnline & 4.26 & 0.83 \\
\hline $\begin{array}{l}\text { 2. I liked our traditional lessons more than the lesson with the use of } \\
\text { PushkinOnline }\end{array}$ & 1.97 & 0.93 \\
\hline $\begin{array}{l}\text { 3. I think that PushkinOnline in-class activities improved my listening skills in } \\
\text { the particular case of the learned topic }\end{array}$ & 4.03 & 0.78 \\
\hline $\begin{array}{l}\text { 4. Individual PushkinOnline grammar activities helped me to comprehend the } \\
\text { aural text }\end{array}$ & 4.06 & 0.78 \\
\hline $\begin{array}{l}\text { 5. Individual PushkinOnline vocabulary activities helped me to comprehend the } \\
\text { aural text }\end{array}$ & 4.77 & 0.43 \\
\hline $\begin{array}{l}\text { 6. After the listening, it was easy for me to answer the multiple choice questions } \\
\text { 7. I think it was easier than usually to understand the main idea and general } \\
\text { information from the text }\end{array}$ & 4.6 & 0.66 \\
\hline $\begin{array}{l}\text { 8. After the listening, it was easy for me to fill in the blanks requiring detailed } \\
\text { information }\end{array}$ & 3.51 & 1.13 \\
\hline $\begin{array}{l}\text { 9. I think it was easier than usually to catch the details (facts, dates, numbers, } \\
\text { names) of the text }\end{array}$ & 4.14 & 0.95 \\
\hline $\begin{array}{l}\text { 10. There were several difficulties I faced when working with PushkinOnline } \\
\text { during the listening lesson* }\end{array}$ & 2.6 & 1.04 \\
\hline
\end{tabular}

Note: the multiple choice questions were addressed to listening for the general information, whereas the fill-inthe-blank items, by contrast, checked listening for the detail. 
Twenty nine students of the experimental group commented positively (score 5 or 4) on PushkinOnline based lesson with a mean rating of 4.26. By comparison, the conventional class without implementation of CALL was preferable for just 2 participants (score 1 or 2 ).

Almost three-quarters of the students $(N=25)$ indicated the positive impact of the applying PushkinOnline activities on their listening performance $(M=4.03)$. According to students, pre-listening vocabulary exercises were more useful for the further comprehension $(M=4.77)$ compared to grammar activities $(M=4.06)$.

Questions No. 6-9 allowed verifying whether the participants' perception of their progress in the different types of listening correlates with the data obtained from comparison of pre-test and post-test results.

Question No. 7 showed that the significant positive effect from working with PushkinOnline with the aim of developing the ability to understand the general idea of the text was noted just by 6 testees (score 4 and 5). Moreover, the exercises targeted to general listening were found to be easy by most of the students $(M=4.6)$ in their response to question No. 6 .

Compared to this, tasks for general listening seemed to participants more complicated $(M=3.51)$ that was revealed by question No. 8. Instead, three quarters of the students $(\mathrm{N}=26)$, answering the question No. 9, indicated that after PushkinOnline based sessions it was easier to them to catch detailed information from the oral text. This generally confirms the conclusions derived from the analysis of the post-test results.

Observations of the researchers and reflection of teachers and students after the intervention stage allow explaining the effectiveness of using CALL in the development of selective listening. Working individually with PushkinOnline resources at a certain period of time in class, students can concentrate on their individual gaps in comprehension, whereas it is difficult to achieve this result working in group without utilizing CALL.

Question No. 10 allowed revealing the problems faced by the students during their work with PushkinOnline resources. More than $50 \%$ of participants noted the difficulty in carrying out fill-in-the-blank items, whereas it was necessary to type in the answers using the Cyrillic keyboard layout. At that, a similar work on paper does not cause difficulties, because in most courses on Russian as a foreign language, students are taught the Cyrillic handwriting. The difficulty in typing on a Cyrillic keyboard layout shows the urgent need for the inclusion of special simulators in the preparatory department curriculum.

Among other difficulties, students have noted the complexity of the interaction with PushkinOnline interface (37\%, $\mathrm{N}=13)$, the complexity in listening comprehension of unfamiliar speakers $(20 \%, \mathrm{~N}=7)$, as well as technical difficulties, for example, when signing in PushkinOnline (14\%, N=5).

\subsection{Discussion}

Though the researchers tried to put in equal conditions all participants of the study it was carried out with a number of restrictions. First of all, a limited number of participants: 68 students and 7 teachers of the Preparatory Department involved in the study and the imbalance in the composition of participants with regard to their native country and native language (most of the students were from China and Vietnam). Some other factors such as the different working experience of instructors, different language abilities of students might interfere with the procedure and influence the results. Besides, the findings of the study were restricted only by one topic, which is "Biography". Finally, the results in each group as well as students' perceptions, as noted by the researchers, varied depending on the experience of the teacher in using CALL in the classroom and his preconceptions about this approach. These restrictions may serve the basis for initiating further research in this area.

The results will be possibly more informative in case the research is conducted involving more participants which allows to prove the main conclusion of this study: the quantitative data of the experiment indicates that CALL approach is most effective in developing selective listening.

\section{Conclusion}

The study has produced data, supporting the effects of computer-assisted listening learning in Russian as a foreign language. The researchers focused their attention on RFL students studying at the preparatory department and preparing for entrance to Russian universities. In this case, non-reciprocal listening is an important communicative skill, which will influence the further academic progress of the students, who will listen to lectures in Russian. The study was conducted in several stages: pre-intervention stage, at which instructors estimated the general level of Russian language proficiency in participants and the degree of their listening skills in familiar topic; training for teachers on using PushkinOnline digital resources in the blended learning format; intervention stage, which consisted of the Russian language lessons on the topic "Biography" using PushkinOnline digital resources; and post-intervention stage, consisting of post-test and survey of the students.

Based on the conducted study, a conclusion was made about the positive effect of CALL approach on the formation of non-reciprocal listening skills in general. At that, this approach had the most significant effect on the shaping of selective listening skills. Presumably, this is because individual work with the educational platform as part of the lesson allows teacher to better work out individual learning problems and gaps of each student, related to both lexical and grammatical difficulties as well as the perception of detail information.

The vast majority of students expressed satisfaction from working with CALL at the Russian language classes. Also some concerns were noted by the students involved in this teaching format: the complexity when working with Cyrillic 
keyboard layout, technical problems, difficulties in the interaction with the program interface, and problems with listening recognition of unfamiliar speaker.

The results of the study can be used in the development of digital educational resources in Russian as a foreign language, in particular, listening to the Russian language, when developing curriculum for teaching Russian as a foreign language. The research illustrates the quantitative data of students' results in listening for general information and selective listening which enables instructors to choose the best strategy for developing listening skills. That is the mail significance of the study.

Further development of the research looks quite promising. It may concern the broadening of participants' composition, as well as topics and context of the study. It is necessary also to examine the use of CALL approach in learning the Russian language from the standpoint of teachers. A comparative study of the effectiveness of using aural texts and videotexts in CALL based teaching of listening in Russian language looks quite challenging.

\section{Acknowledgements}

This study was supported by the Ministry of Education and Science of the Russian Federation and conducted under the project 27.270.2016/NM. Also, the authors would like to thank the instructors of the preparatory department who agreed to participate in the research and contributed significantly to its outcome.

\section{References}

Barani, G., (2011). The relationship between Computer Assisted Language Learning (CALL) and listening skill of Iranian EFL learners. Procedia - Social and Behavioral Sciences, 15, 4059-4063.

Bax, S., (2003). CALL - past, present and future. System, 31(1), 13-28.

Beatty, K., (2010). Teaching and researching computer-assisted language learning. London, UK, Pearson Education.

Brett, P., (1995). Multimedia for listening comprehension: The design of a multimedia-based resource for developing listening skills. System, 23(1), 77-85.

Butler-Pascoe, M.E., (2011). The history of CALL. International Journal of computer-assisted language learning and Teaching, 1(1), 16-32.

Chambers, A., (2010). Computer-assisted language learning: Mapping the territory. Language Teaching, 43(1), 113122.

Chapelle, C.A. (2003). English language learning and technology: Lectures on applied linguistics in the age of information and communication technology. Amsterdam: John Benjamins Pub.

Chen, L., Zhang, R., and Liu, C., (2013). Listening strategy use and influential factors in web-based computer assisted language learning. Journal of Computer Assisted Learning, 30(3), 207-219.

Davies, G., (2005). UCALL Conference keynote: Computer assisted language learning: Where are we now and where are we going? [Online] Available http://www.camsoftpartners.co.uk/docs/UCALL_Keynote.htm (June 26, 2016).

Felix, U., (2008). The unreasonable effectiveness of CALL: What have we learned in two decades of research? ReCALL, 20(2), 141-161.

Field, J., (2009). Listening in the language classroom. Cambridge, Cambridge University Press.

Grgurovic, M., Chapelle, C., and Shelley, M., (2013). A meta-analysis of effectiveness studies on computer technologysupported language learning. ReCALL Journal, 25(2), 165-198.

Gruba, P., (2006), Playing the videotext: A media literacy perspective on video-mediated L2 listening. Language Learning \& Technology, 10(2). 77-92.

Hegelheimer, V., and Tower, D., (2004). Using CALL in the classroom: Analyzing student interactions within an authentic CALL program. System, 32(2), 185-205.

Horn, M.B., and Staker, H., (2014). Blended: Using disruptive innovation to improve schools. San Francisco, CA, JohnWiley \& Sons.

Hubbard, P., (2009). General introduction, Computer Assisted Language Learning, Foundations of CALL. Critical Concepts in Linguistics, New York: Routledge, 1-20, (Volume 1).

Hsu, J., (1994). Computer assisted language learning (CALL): The effect of ESL students' use of interactional modifications on listening comprehension (Unpublished doctoral dissertation). Department of Curriculum and Instruction, College of Education, Iowa State University, Ames, IA.

Jakobsdottir, S., and Hooper, S., (1995). Computer-assisted foreign language learning: Effects of text, context, and gender on listening comprehension and motivation. Educational Technology Research and Development, 43(4), 43-59.

Jones, L.C. (2003). Supporting listening comprehension and vocabulary acquisition with multimedia annotations: The students' voice. CALICO Journal, 21(1), 41-65.

Jones, L., (2006). Listening comprehension in multimedia environments. In L. Ducate and N. Arnold (Eds.), Calling on CALL: From theory and research to new directions in foreign language teaching. CALICO Monograph Series, San Marcos, Texas State University, 5, 99-126. 
Jones, L., (2009). Supporting student differences in listening comprehension and vocabulary learning with multimedia annotations. CALICO Journal, 26(2), 267-289.

Levy, M., (2009), Technologies in use for second language learning. The Modern Language Journal, 93, 769-782.

Nachoua, H., (2012). Computer-assisted language learning for improving students' listening skill. Procedia - Social and Behavioral Sciences, 69(24), 1150-1159.

O'Bryan, A., and Hegelheimer, V., (2007). Integrating CALL into the classroom: The role of podcasting in an ESL listening strategies course. ReCALL, 19(2), 162-180.

Rost, M., (2002). Teaching and researching listening. Harlow: Longman.

Roussel, S., (2011). A computer assisted method to track listening strategies in second language learning. $\operatorname{ReCALL}, 23(02), 98-116$.

Seo, K., (2002). The effect of visuals on listening comprehension: A study of Japanese learners' listening strategies. International Journal of Listening, 16(1), 57-81.

Sigalov, A.B., and Skuratov, A., (2012). Educational portals and open educational resources in the Russian Federation. Moscow: IITE.

Smidt, E., and Hegelheimer, V., (2004). Effects of Online Academic Lectures on ESL Listening Comprehension, Incidental Vocabulary Acquisition, and Strategy Use. Computer Assisted Language Learning 17(5), 525-564.

Soboleva, O. \& Tronenko, N. (2002). A Russian multimedia learning package for classroom use and selfstudy. Computer Assisted Language Learning, 15 (5). 483-499.

Sueyoshi, A., and Hardison, D.M., (2005). The role of gestures and facial cues in second language listening comprehension. Language Learning, 55(4), 661-699.

Taylor, G., (2005). Perceived processing strategies of students watching captioned video. Foreign Language Annals, $38(3), 422-427$

Tomlinson, B., and Whittaker, C., (2013). Blended learning in English language teaching: Course design and implementation. London: British Council.

Wakabayashi S. (1998). Multimedia-databased interactive practice for L2 listening comprehension. Multimedia CALL: Theory and Practice. Exeter: Intellect Books.

Warschauer, M., and Kern, R., (2000). Network-based language teaching. Cambridge University Press, Cambridge, UK.

Wilson, J.J., (2008). How to teach listening. Harlow: Longman.

Winke, P., Gass, S., and Sydorenko, T., (2010). The effects of captioning videos used for foreign language listening activities. Language Learning \& Technology, 14(1), 65-86.

Yang, Y.-T. C., and Chan, C.-Y., (2008). Comprehensive evaluation criteria for English learning websites using expert validity surveys. Computers \& Education, 51, 403-422.

Zhao, Y. (2003). Recent developments in technology and language learning: A literature review and meta-analysis. CALICO Journal, 21(1), 7-27. 